\title{
Featured Artist - Zhang Huan
}

\section{艺术家聚焦 : 张洹}

\author{
Stephen K. Levine \\ The European Graduate School, Switzerland
}

\begin{abstract}
Zhang Huan, 張洹; born 1965, is an internationally known contemporary Chinese artist whose work has been exhibited in numerous galleries and museums both in China and in the West. He is best known as a performance artist in the West, making pieces involving his own body and that of others and often subjecting them to extreme conditions. However, even during this period of his work, Zhang Huan has always tried to show spiritual being manifesting itself through bodily suffering. In recent years his artwork has taken a more obvious spiritual turn, using ash from temple incense and often referring to Buddhist themes and images expressing the transitory character of human life.
\end{abstract}

Keywords: Performance art, the body, spiritual being, life and death, Buddhism, temple ash paintings, Chinese tradition and modern art, expanding the boundaries of art, art and the political, questioning society, art and daily life

\section{摘要}

张洹，生于1965年，是一位国际知名的中国当代艺术家，他的作品曾在中国和西方的众多 画廊和博物馆展出。他对于西方最出名的是作为表演艺术家，经常通过让他自己和他人身 体处于极端条件下，来创造作品。然而，即使在他的这段工作期间，张洹也总是试图通 过身体上的痛苦展示出精神上的主张。近年来，他的艺术作品采用了更加明显的精神转 向，使用了寺庙香火中的灰灿，并经常提到佛教主题和表达人类生活短暂特征的意象。

关键词: 表演艺术，身体，精神存在，生死，佛教，寺庙灰画，中国传统和现代艺术，拓展艺术边界，艺术 和政治, 质疑社会, 艺术和日常生活的界限

The following interview was conducted over the Internet in early 2018.

1. Stephen K. Levine: Your work as an artist has gone through many phases. Can you briefly give us an outline of your development?

Zhang Huan: I moved from my hometown to Beijing and spent 8 years there as a professional artist. In 1998, as I gained greater recognition as a performance artist, I relocated to New York for an additional 8 years. At the end of 2005 I came back to China and started to work with such kinds of materials as incense ash-paintings, oil paintings, sculptures, public artworks, cowhide, woodcarving and woodcut, etc. I was lucky enough to follow my heart and achieve my goals. 
2. SKL: In the West, you are primarily known as a performance artist. Can you speak about the role of performance in your work? Is it still in the center?

$\mathrm{ZH}$ : People will naturally adopt corresponding ways to express their many ideas due to differences in age and living conditions. I don't like to repeat what I have done. I will continue to do performance art if new inspiration occurs.My artwork can be considered as a whole piece through which my outlooks on life and the world are expressed. Now I use various media and skills in my works and so the patterns of manifestation seem different from the previous pieces. The kernel, however, remains the same because the DNA within me will not be changed.

3. SKL: Most recently it seems your work has taken a spiritual turn. Please comment on that.

$\mathrm{ZH}$ : Many of the elements shown in my works include human beings' memories, their happiness, births and deaths, faith and belief and their brutish nature; my words aim to arouse peoples' attention to themselves, the worlds they move through and the environments they are living in. Nowadays, I see this as an era full of loneliness, anxiety and hopelessness. The evolution of mankind will be ineffective in the end.

4. SKL: Our readers would be particularly interested in how your work as an artist draws from traditional Chinese sources as well as having been influenced by Western developments in the arts. Please comment.

$\mathrm{ZH}$ : I spent 8 years living in other parts of the earth and I travelled to many countries during that time. I found that it was while I was at a distance from my native land that I could realize myself, my tradition and the most essential treasure of my ancestors more clearly. I returned to China at the end of 2005 and, at once, found new inspiration and media for creation. I cherished the incense ash burnt in temples in Shanghai and the surrounding areas and I was drawn to the wooden windows and doors of the old buildings that formed the outskirts of the city. The characteristic traditions of China and the desires of the modernists became the source of my art creation. My new media and world experiences had broadened the scope of my creation and brought me a more powerful self-confidence and an independent mind both of which were the important things I treasured. It looks like everything is determined by fate. What is important for artists is to make choices based on their own standards, to make interesting and familiar things according to their own surroundings, to discover the seemingly meaningless in ordinary life and to do art in their own way.

5. SKL: Some see your art within a political perspective. How important to you has the political dimension been in your development? Is it still central to your thinking and practice?

$\mathrm{ZH}$ : My art is not influenced by politics either in Beijing or New York - whether they are current or events that happened in the past. My biggest enemy is myself. "Zhang Huan, born in Henan in 1965." This statement is what I need to make as an artist throughout my life. 
6. SKL: What is your vision of the future for you, personally, and as an artist?

ZH: I'm a glutton for work. I forgot loneliness and death when I was busy working. I think one side of an artist's life is to extend the branches of art and the other side is to leave art and expand its frontier. Maybe, in fact, it is to blur the definition of art and re-define it. I like to depart from art and to expand its boundary. I want to complicate its definition and redefine it. It does not matter if one is an artist, an entrepreneur a politician - one should have the brain of a magician. He is the leader to guide others. At the same time, people surrounding him cannot predict what he will do next. You won't imagine what I am going to do next. I don't know either.

7. SKL: Our journal has a particular focus on the relation of art to education and therapy. How would you see your work within that context?

$\mathrm{ZH}$ : I have thoughts about daily life, traditional culture and the current environment and love to produce the art pieces that move me most deeply. When I do art, I just follow my heart and focus on the artwork. I think people from different backgrounds can add more meaning and significance to my works - that is what we need for art and for cultural communication. I would like to say that art is such an important part of our lives; people can feel more and learn more from art works.

SKL: What would you like to leave as your legacy - both as a person and an artist?

$\mathrm{ZH}$ : As a person and an artist, my principle is to keep focusing on reality and do more for society. Art comes from daily life and it should reveal and serve people in return.In my view as an artist, I believe our important task is to raise questions to the society we live in and to its art, too. The value of contemporary art arises from creating artworks that may represent the spirit of the era. I will be happy if my works can inspire people in this era and in the future.

SKL: Do you have a statement about your work that we can print in the journal?

$\mathrm{ZH}$ : Please see the following:

I invited 3 calligraphers to write texts on my face from early morning until night. I told them what they should write and I continued to keep a serious attitude when they were writing the texts - even when my face turned dark. My face followed the daylight till it slowly darkened. I could not tell who I was. My identity had disappeared.

This work speaks about a family story; a spirit of family. In the middle of my forehead, the text means "Move the Mountain by Fool (Yu Kong Yi Shan)". This traditional Chinese story is known by all ordinary people and is a story about determination and challenge. If you really want to do something, then it could actually happen. Other texts are about human fate - like a kind of divination. Your eyes, nose, mouth, ears, cheekbone and moles indicate your future, wealth, sex, disease, etc. I always feel that some mysterious fate surrounded human life that we could do nothing about; we could do nothing to control it. It just happened.

The shape of Three Heads Six Arms came from my correlation with the Chinese mythological character Nezha, the Protector. The inspiration came from Tibetan Buddha sculptures. I replaced two of the three Buddha heads with human heads. Three Heads Six Arms echoes the changing reality for Chinese people today and also reflects the 

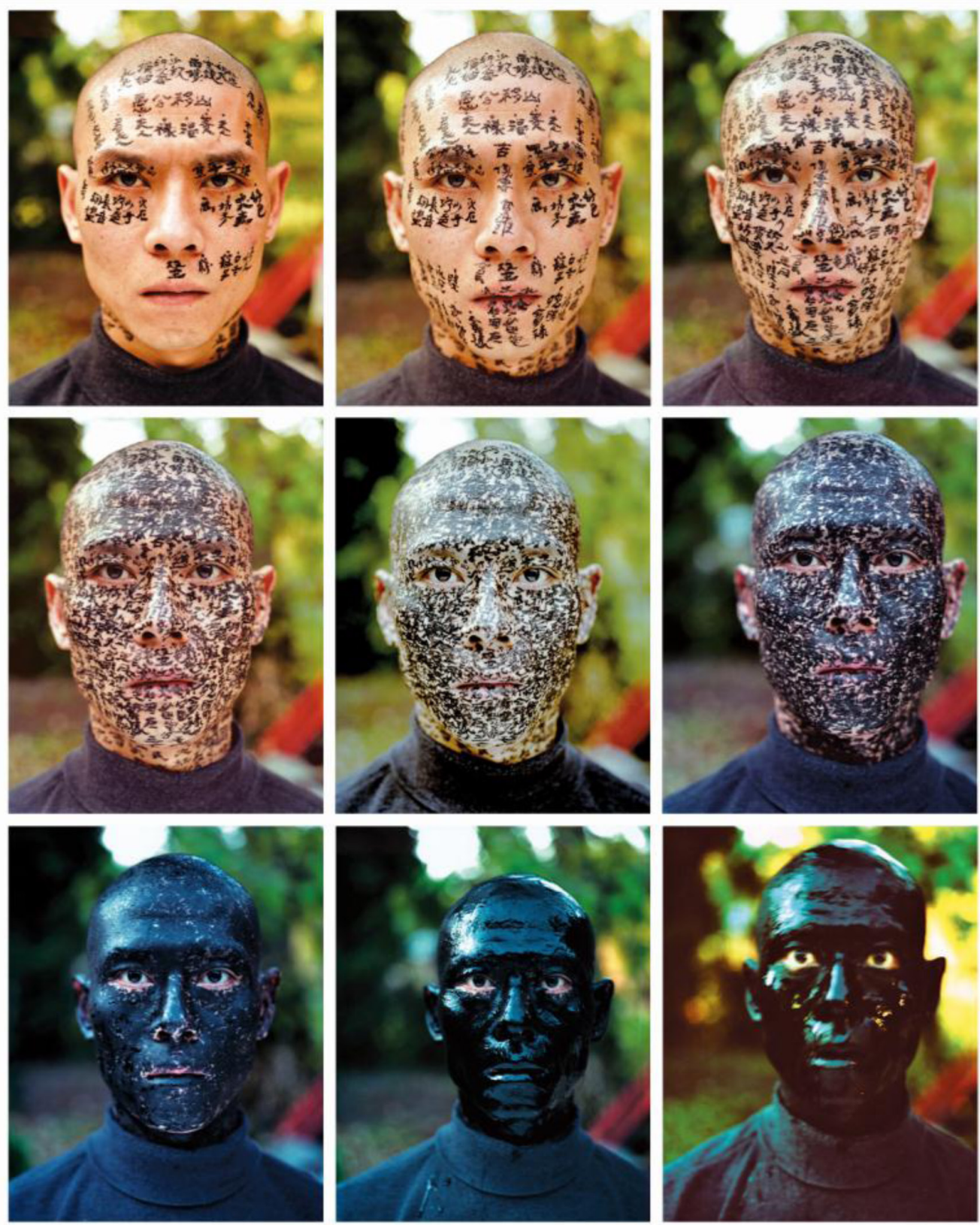

FIGURE 1 | Family Tree 2000, New York, USA, Courtesy of Zhang Huan Studio

attitude by which humankind has conquered nature - even reflecting deeds of volition and hope.

HeheXiexie is an image of two sitting pandas with dreams in their hearts; they are righteous and courageous, persevering and optimistic as well as being tolerant and generous. The two pandas are named Hehe and Xiexie, which, jointly, means harmony- 


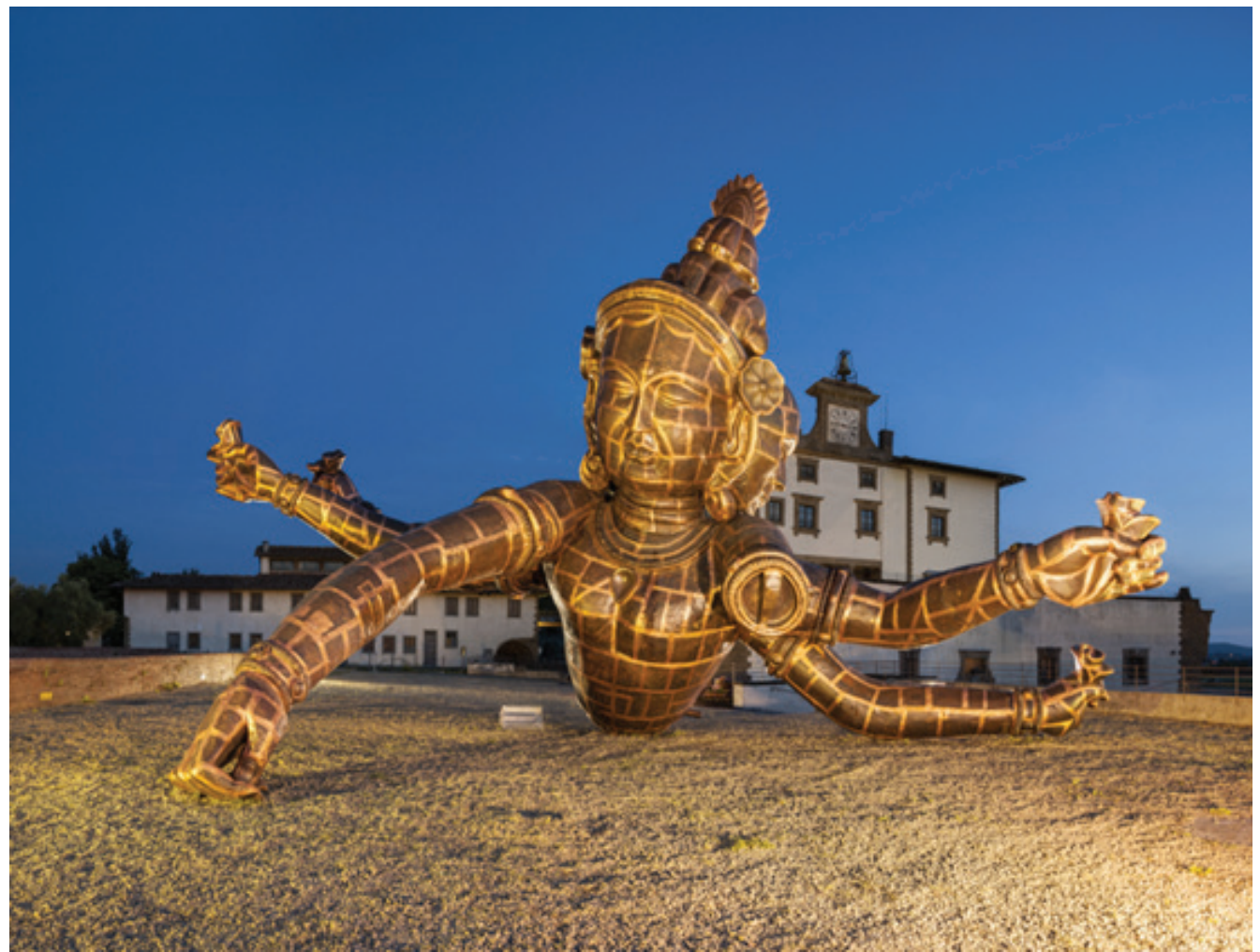

FIGURE 2 | Three Heads Six Arms: 2008, Steel and Copper, 315 x 709 x 394 inches $(800 \times 1800 \times 1000 \mathrm{~cm})$ Forte di Belvedere, Florence, Italy. Photos: Guido Cozzi, Courtesy of Zhang Huan Studio

this represents the shared aspirations of people from all over the world. In honor of the Shanghai World Expo 2010, this piece of work is a permanent public sculpture.

The inspiration for Rising came from my reflection on the living spaces of mankind and has numerous peace pigeons landing on the body of a running creature from outer space. In the modern world, living space is becoming more and more crowded; more people and animals are sharing the same space on the earth which, in turn, is making available space smaller and smaller. Through the monster-shaped tree, I would like to advocate the protection of ecology and the harmonious relationship between humans and nature. The pigeons in the tree symbolize the peace of the world and the beautiful city life shared by both mankind and nature.

Incense ash is meaningful to me. It is my invention to use incense ash in paintings. In my eyes, ash is not only a material; it also carries the believers' hope and soul. The ash artworks convey the collective memory, collective soul and collective blessings of the people in China.

The inspiration came from classical Chinese Literati paintings and bird-and-flower paintings. 


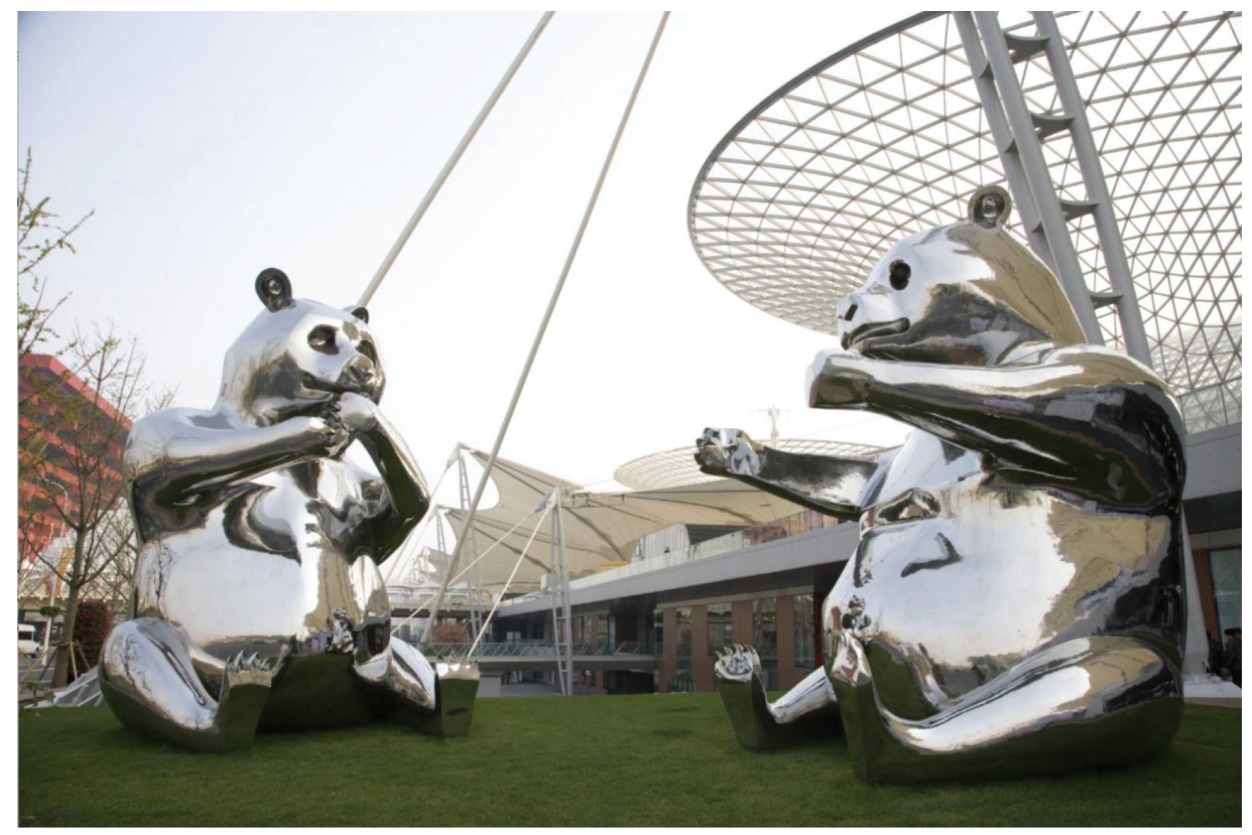

FIGURE 3 | HeheXiexie: 2010, Mirror Finished Stainless Steel. Left: 600 x 420 x $380 \mathrm{~cm}$. Right: 600 x 426 x $390 \mathrm{~cm}$. Permanently Reserved in Shanghai Expo Site.

Courtesy of Zhang Huan Studio

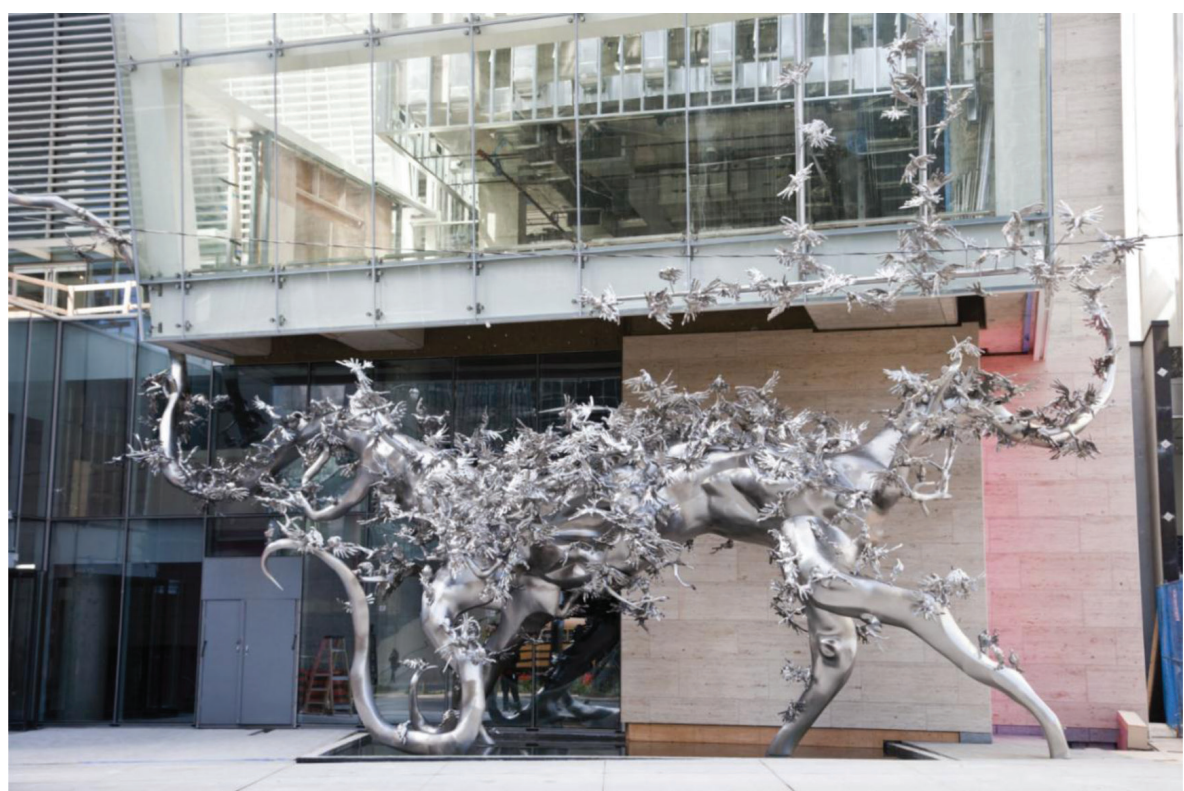

FIGURE 4 | Rising: 2010-2012, Stainless Steel, 865 x 780 x 189 inches (2198 x 1980 x 480 cm). Permanent Sculpture at Shangri-La Hotel, Toronto, Canada. Courtesy of Shangri-La Hotel, Toronto and Zhang Huan Studio 


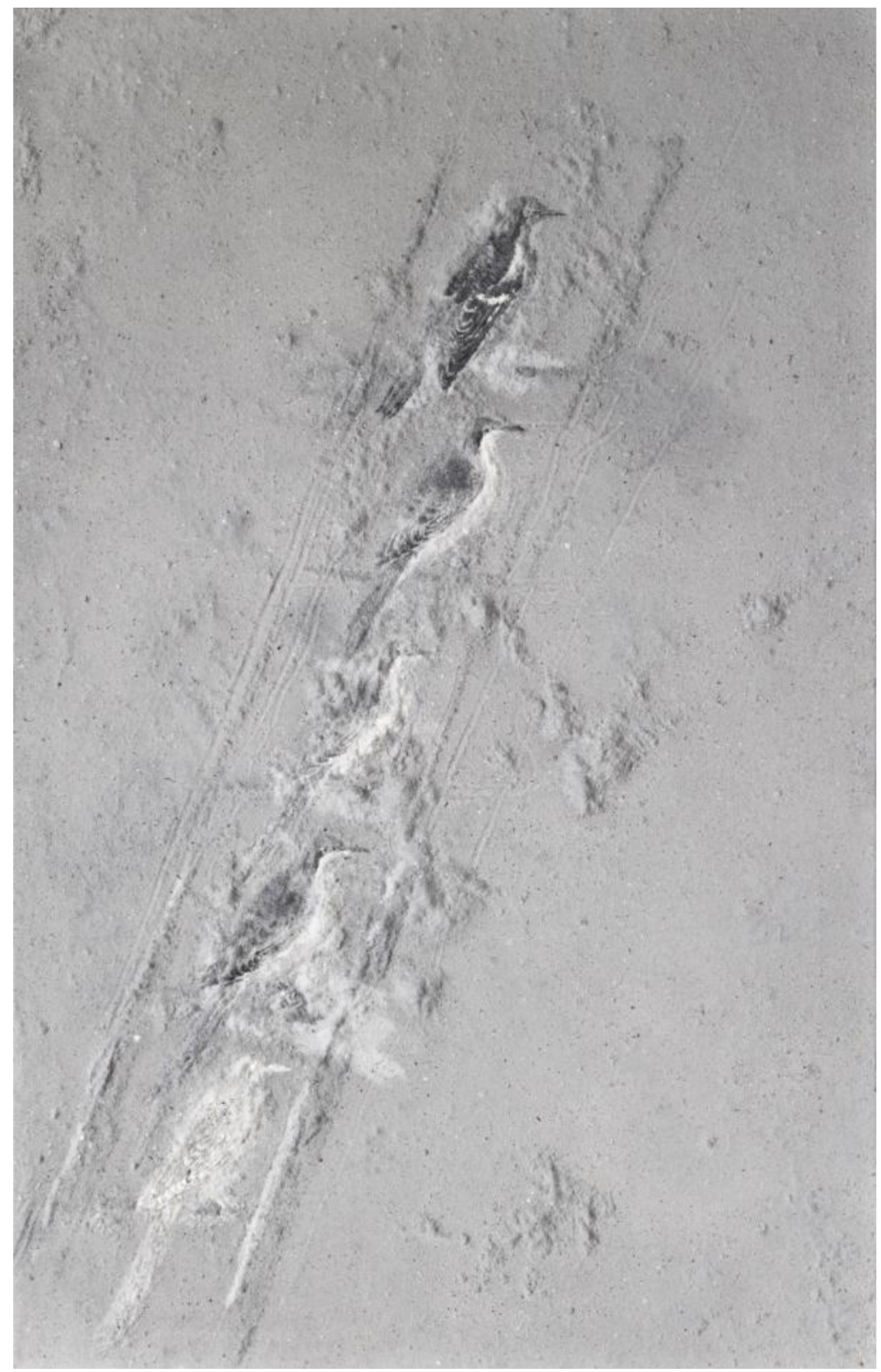

FIGURE 5 | Forgetting Sorrow No.6: 2012, ash on linen, 250x160cm. Courtesy of Zhang Huan Studio 


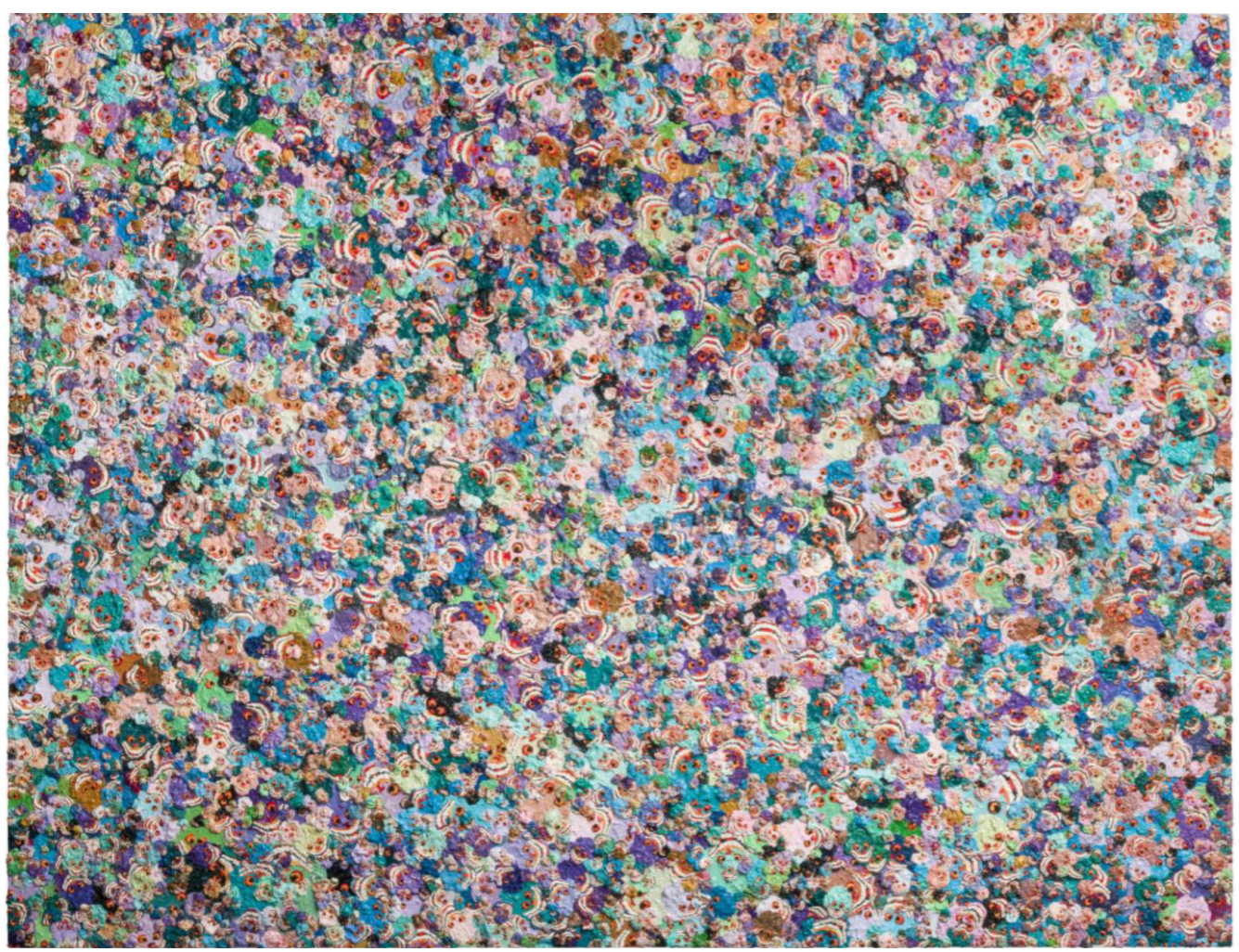

FIGURE 6 | Poppy Field in Spring No.1: 2013, oil on linen, 153x200cm.

Courtesy of Zhang Huan Studio

To me, life and death bring feelings of mystery, beauty, fear, loneliness and eternity a life lesson that cannot be surpassed.

The images of skulls are extremely exaggerated, unrealistic and animalistic in style and are the symbol of Tibetan Buddhism. Within skulls there are countless spirits that express the birth, aging, illness and death of humanity. I see them as the origin of human beings' development, their evolution and their decline. Unreal desires for happiness and freedom are shown in the paintings. Premature life and spirit sprouting in spring will reincarnate endlessly in the Poppy Fields.

\section{About the Author}

Stephen K. Levine, Ph. D., D.S.Sc., REAT, Dean of the Doctoral Program in Expressive Arts in the Division of Arts, Health and Society at The European Graduate School (Switzerland), Professor Emeritus at York University (Toronto). Email: stephen.levine@egs.edu

\section{About Zhang Huan}

Zhang Huan, Contemporary artist. Lives and works in Shanghai and New York. Email: zhanghuan@zhanghuan.com 